\title{
Therapeutic communication between health workers and patients concerning diabetes mellitus care
}

\author{
Marta Maria Coelho Damasceno ${ }^{1}$ \\ Maria Lúcia Zanetti \\ Emilia Campos de Carvalho ${ }^{3}$ \\ Carla Regina de Souza Teixeira² \\ Márcio Flávio Moura de Araújo ${ }^{4}$ \\ Ana Maria Parente Garcia Alencar ${ }^{5}$
}

The objective of this cross-sectional study was to analyze therapeutic communication techniques used by health workers with patients under care for diabetes mellitus. Data were collected in 2010 in a public facility in the interior of Ceará, Brazil using video camera equipment and direct observation. Results showed that the most frequently used techniques within the "expression" group were: asking questions, voicing interest, and using descriptive phrases. The most frequently used technique within the "clarification" group was: asking the patient to specify the agent of action. Finally, in regard to the "validation" group, only the technique "summarizing content of the interaction" was employed. The conclusion is that despite the use of communication techniques on the part of professionals, there is still an alarming gap concerning communication skills. Such skills should be allied with technical expertise to enable the delivery of qualified care to individuals with diabetes mellitus.

Descriptors: Communication; Diabetes Mellitus; Interpersonal Relationships.

\footnotetext{
${ }^{1} \mathrm{PhD}$, Professor, Universidade Federal do Ceará, Brazil.

2 PhD, Associate Professor, Escola de Enfermagem de Ribeirão Preto, Universidade de São Paulo, WHO Collaborating Centre for Nursing Research Development, Brazil.

${ }^{3}$ PhD, Full Professor, Escola de Enfermagem de Ribeirão Preto, Universidade de São Paulo, WHO Collaborating Centre for Nursing Research Development, Brazil.

${ }^{4}$ Doctoral student, Universidade Federal do Ceará, Brazil. Assistant Professor, Universidade Federal do Maranhão, Brazil.

${ }^{5}$ Doctoral student, Universidade Federal do Ceará, Brasil. Adjunct Professor, Universidade Regional do Cariri, Brasil.
}

Corresponding Author:

Marta Maria Coelho Damasceno

Universidade Federal do Ceará. Departamento de Enfermagem

Rua Alexandre Baraúna, 949

Bairro: Rodolfo Teófilo

CEP: 60430-160, Fortaleza, CE, Brasil

E-mail: martadamasceno@terra.com.br 


\section{A comunicação terapêutica entre profissionais e pacientes na atenção em diabetes mellitus}

Objetivou-se, por este estudo transversal, analisar as técnicas de comunicação terapêutica entre profissionais e pacientes na atenção em diabetes mellitus. Os dados foram coletados em uma instituição pública de um município no interior do Ceará, Brasil, em 2010, por meio de equipamentos de vídeo e observação direta. Os resultados mostraram que as técnicas do grupo de expressão mais utilizadas foram: fazer perguntas, verbalizar interesse e usar frases descritivas. Quanto às do grupo de clarificação, sobressaiu solicitar ao paciente que precise o agente da ação. Em relação às de validação, apenas foi utilizada a técnica de sumarizar o conteúdo da interação. Conclui-se que, apesar do emprego de técnicas comunicacionais pelos profissionais, ainda é preocupante a lacuna referente à habilidade em comunicação, a qual deve ser aliada à competência técnica, para assim propiciar o cuidado qualificado às pessoas com diabetes mellitus.

Descritores: Comunicação; Diabetes Mellitus; Relações Interpessoais.

\section{La comunicación terapéutica entre profesionales y pacientes en la atención en diabetes mellitus}

Este estudio transversal tuvo como objetivo analizar las técnicas de comunicación terapéutica entre profesionales y pacientes en la atención en diabetes mellitus. Los datos se recogieron en una institución pública de Ceará-Brasil, en 2010, con equipos de video y observación directa. Los resultados mostraron que las técnicas del grupo de expresión más utilizadas fueron: hacer preguntas, expresar interés y usar frases descriptivas. Con relación a las del grupo de clarificación sobresalió solicitar al paciente que necesite el agente de la acción. Con relación a las de validación, apenas se utilizó las de organizar el contenido de la interacción. Se concluye que a pesar del uso de técnicas de comunicación por los profesionales, aun es preocupante la laguna con relación a la habilidad en comunicación, que debe ser aliada a la capacidad técnica, para así propiciar el cuidado calificado a las personas con diabetes mellitus.

Descriptores: Comunicación; Diabetes Mellitus; Las Relaciones Interpersonales.

\section{Introduction}

Communication, the means through which people interact with each other, through sharing sent and received messages, is effective only when both sender and receiver understand the message. When communication occurs between health workers and patients and is intended to help patients to cope with problems, relate with another, adapt to what cannot be changed, and face obstacles to one's self-realization, it is called therapeutic communication ${ }^{(1)}$.

Strategies of therapeutic communication are suggested to facilitate interaction between health workers and patients, which according to one of the classifications most disseminated in Brazil, are categorized into three groups: expression, clarification and validation. These techniques should be used in a conscious, coherent, non-repetitive manner, and when necessary, associated with other strategies to facilitate the development of a therapeutic relationship. This set of techniques implies that professionals should consider both the verbal and non-verbal aspects of communication during interaction(2).

Even though communication is acknowledged as essential, recent studies ${ }^{(3-6)}$ indicate that the communication process or interpersonal relationship among patients, nurses and other health workers is still not considered to be very effective. Communication difficulties are observed in clinical practice between professionals and patients ${ }^{(7-8)}$, which can strongly affect 
satisfaction, treatment adherence, and, consequently, health outcomes, suggesting the need to prepare the professionals involved in regard to both human and technical matters.

Those interested in the subject have highlighted the value of effective communication for nurses in hospital practice $^{(9)}$, as well as for physicians and nurses in primary heath care services ${ }^{(7,10-11)}$. Despite the recognition of the importance of the communication process in the care provided to individuals with diabetes mellitus (DM), studies addressing communication techniques employed in the daily practice of professionals dealing with these patients were not found, which justifies this study.

When we acknowledge that DM is a complex disease that requires life style and behavioral changes in the routine of those affected by it, success in coping with its demands and treatment depends on many factors, among which effective communication between patients and health workers stands out. In this context, health workers should ally technical expertise with the use of new competencies and skills to improve communication with patients and help them to more safely cope with the challenges imposed by the disease ${ }^{(12)}$.

Additionally, competent communication implies daily implementation of strategies in which the professionals involved in the communication process appropriately use verbal and non-verbal strategies to enable more effective communication ${ }^{(13}$.

Therefore, this study's objective was to analyze the techniques of therapeutic communication used between health workers and patients during care provided for DM.

\section{Method}

This cross-sectional study was developed in the Integrated Center of Diabetes and Hypertension in a city in the interior of Ceará, Brazil from April to June 2010. The sample was composed of all the health workers with higher education - one nurse, two nutritionists and one physician - responsible for the individual care provided in this facility to individuals with DM and 24 patients with DM.

A checklist based on the theoretical framework concerning therapeutic communication strategies ${ }^{(2)}$ along with a field diary and filming equipment were used to collect data.

The form contains the three groups of therapeutic communication techniques: expression, clarification and validation. The techniques that help to describe the experience and expression of thoughts and feelings were organized within the "expression" group and include: using silence therapeutically, listening reflectively, voicing acknowledgement, voicing interest, phrases that are open to interpretation, repeating the last words used by the patient, making questions, returning the question asked, using descriptive phrases, allowing the patient to choose the subject, putting the main idea into focus, verbalizing doubts, saying 'no', encouraging the expression of underlying feelings, and using humor therapeutically(2).

Clarification includes techniques that enable clarifying what is expressed by patients, such as: encouraging comparisons, asking patients to clarify uncommon terms, to specify the agent of an action and to describe events in a logical sequence. In turn, the techniques in the "validation" group enable the establishment of a common meaning of what is expressed, including repeating the patient's message, asking the patient to repeat what was said, and summarizing the content of interaction(2).

Direct observation was used to collect data along with filming the consultations to the patients with DM provided by the health workers. Data obtained through observation were concomitantly recorded in one form and the filmed content was later analyzed based on this same form. Data concerning aspects of non-verbal communication such as gestures and facial expressions were noted in a field diary to complement understanding of verbal utterances. Each professional was observed four times and filmed twice on different days and occasions for approximately 20 minutes, totaling 24 consultations and 480 minutes of recording.

The project was approved by the Ethics Research Committee Concerning Human Subjects at the Federal University of Ceará (protocol 47/10). Professionals and patients were informed of the study's objectives and nature. All participants consented with the data collection procedures and signed free and informed consent forms. The health workers are identified by the letters N (nurse), P (physician), N1 (Nutritionist 1) and N2 (Nutritionist 2).

Data obtained through direct observation and filming with video camera equipment are presented in tables with absolute frequency and those recorded in the field diary are presented in a discursive manner. Data were analyzed in light of the theoretical framework of Stefanelli ${ }^{(2)}$ according to the therapeutic communication strategies classified in the groups "expression", "clarification", and "validation" and based on the literature on the subject. 


\section{Results}

The results described as follows were obtained through observation and the filming of consultations provided by health workers to patients with DM. The frequencies observed concerning the different communication techniques were: 102 for expression, 8 for clarification, and 8 for validation.

Data concerning expression techniques indicate that verbalizing interest, asking questions, and using descriptive phrases were the most frequently used. However, listening reflectively, a technique considered extremely important, was identified only in the care provided by the nurse and Nutritionist 2. If compared to other professionals, the nurse was the one who most frequently used the techniques concerning the expression group (Table 1 ).

Table 1 - Numerical distribution of techniques concerning the "expression" group identified during consultations provided to patients with DM by the health workers. Ceará, Brazil, 2010

\begin{tabular}{|c|c|c|c|c|c|}
\hline \multirow{2}{*}{ Techniques of the "expression" group } & \multicolumn{4}{|c|}{ Health workers } & \multirow{2}{*}{ Total } \\
\hline & $\mathbf{N}$ & $\mathbf{P}$ & N1 & N2 & \\
\hline 1. Using silence therapeutically & - & - & - & - & 0 \\
\hline 2. Listening reflectively & 6 & - & - & 6 & 12 \\
\hline 3. Verbalizing acknowledgment & 3 & - & - & - & 3 \\
\hline 4. Verbalizing interest & 6 & 6 & 6 & 6 & 24 \\
\hline 5. Using phrases that are open to interpretation & - & - & - & - & 0 \\
\hline 6. Repeating the last words the patient said & - & - & - & - & 0 \\
\hline 7. Asking questions & 6 & 6 & 6 & 6 & 24 \\
\hline 8. Returned the question asked & - & - & - & - & 0 \\
\hline 9. Using descriptive phrases & 6 & 6 & 4 & 6 & 22 \\
\hline 10. Allowing the patient to choose the subject & - & - & - & - & 0 \\
\hline 11. Putting the main idea into focus & 4 & 4 & - & - & 8 \\
\hline 12. Voicing doubts & - & - & - & - & 0 \\
\hline 13. Saying 'no' & - & 2 & 3 & - & 5 \\
\hline 14. Encouraging the expression of underlying feelings & - & - & - & - & 0 \\
\hline 15. Using humor therapeutically & - & 2 & - & - & 2 \\
\hline Total & 31 & 26 & 19 & 24 & 102 \\
\hline
\end{tabular}

Though with a discrete frequency, "asking the patient to specify the agent of action" was the technique, within the "clarification" group, most frequently observed in consultations provided by the nurse, physician and Nutritionist 1 . It is worth noting that only the physician employed the technique "encouraging comparisons".
Therefore, the physician was the professional who most frequently used the techniques from the "clarification" group (Table 2 ).

In regard to the "validation" group, Nutritionist 2 was the professional who most frequently used the technique "summarizing content of interaction" (Table 3).

Table 2 - Numerical distribution of the techniques from the "clarification" group during consultations provided to patients with DM by health workers. Ceará, Brazil, 2010

\begin{tabular}{|c|c|c|c|c|c|}
\hline \multirow{2}{*}{ Techniques of the "clarification" group } & \multicolumn{4}{|c|}{ Health workers } & \multirow{2}{*}{ Total } \\
\hline & $\mathbf{N}$ & $\mathbf{P}$ & N1 & N2 & \\
\hline 1. Encouraging comparisons & - & 2 & - & - & 2 \\
\hline 2. Asking the patient to clarify uncommon terms & - & - & - & - & 0 \\
\hline 3. Asking the patient to specify the agent of action & 2 & 2 & 2 & - & 6 \\
\hline 4. Describing the events in a logical sequence & - & - & - & - & 0 \\
\hline Total & 2 & 4 & 2 & - & 8 \\
\hline
\end{tabular}


Table 3 - Numerical distribution of the techniques within the "validation" group identified during consultations provided to patients with DM by health workers. Ceará, Brazil, 2010.

\begin{tabular}{|c|c|c|c|c|c|}
\hline \multirow{2}{*}{ Techniques of the "validation" group } & \multicolumn{4}{|c|}{ Health workers } & \multirow{2}{*}{ Total } \\
\hline & $\mathbf{N}$ & $\mathbf{P}$ & N1 & N2 & \\
\hline 1. Repeating the patient's message & - & - & - & - & 0 \\
\hline 2. Asking the patient to repeat what was said & - & - & - & - & 0 \\
\hline 3. Summarizing content of interaction & 1 & 1 & - & 6 & 8 \\
\hline Total & 1 & 1 & - & 6 & 8 \\
\hline
\end{tabular}

According to the data obtained, the nurse was the professional who most frequently used the techniques from the "expression" group, the physician most frequently used those from the "clarification" group and Nutritionist 2 most frequently used those from the "validation" group. It is worth noting the number of techniques that compose each group, the techniques that were not observed at all, and the low frequency with which the techniques, in general, were employed, though the techniques from the "expression" group were the most frequently adopted by the studied professionals.

\section{Discussion}

The workers investigated in this study employed different groups of communication techniques, but mostly those from the "expression" group. Even though this was the most frequently used group, only some of its techniques, such as "asking questions", "voicing interest" and "using descriptive phrases," were frequently observed. In this context, similar results were reported in studies addressing workers in the hospital environment ${ }^{(6,14)}$.

"Asking questions", a technique frequently used in consultations provided by all the studied participants, is extremely important in the interpersonal relationships established with patients, because it allows one to continue dialogue and enables the expression of feelings and the collection of relevant information, among other objectives. Its use, however, is controversial because the manner one asks questions may impede obtaining results expected from the communicative process. Thus, questions should be clearly asked with a vocabulary appropriate to the patient, according to age, educational background, and current context of life ${ }^{(2)}$.

The studied professionals used this technique in most of their interactions, which is consistent with the results reported in another study ${ }^{(15)}$. Even though Nutritionist 1 used the technique "asking questions", she used terms such as "anamnesis", "dyslipidemia" and "glucose levels" without, however, clarifying them, in addition to the fact she asked many questions at the same time. It is important to keep in mind that "questions should be used wisely so that the patient does not think that $\mathrm{s} /$ he only has to answer questions and adopt a passive behavior"(2). This type of communication was also observed in a study addressing the physicianpatient relationship(7).

The management inherent to DM requires health professionals not only to have technical expertise concerning the disease but also the ability to identify the extent patients understand questions, to collect data in a manner consistent with patients' real needs, and ensure quality of care delivery. Questions should encourage the patient to adopt an active and participative behavior capable of encouraging self-care, which is considered one of the most important goals for managing the disease $^{(16)}$.

Additionally, the quality of communication between health workers and patients can substantially influence treatment efficiency, since dialogue and communication can improve understanding of a problem and enable better acknowledgment of guidance and recommendations, so important in DM care ${ }^{(17)}$.

Verbalizing interest, which consists of perceiving another as a person by one's attitudes ${ }^{(2)}$, was observed in all consultations and implemented by all the studied workers, in agreement with another study addressing the subject ${ }^{(6)}$. This category is apparent in all situations in which patients were approached by name and received at the office's door. Additionally, in most consultations, professionals shook the patients' hands and complimented them for attending the scheduled consultation.

Demonstration of interest on the part of the professional encourages patients to more effectively participate in their treatment and self-care ${ }^{(1-2)}$. It is also a resource to establish trust and bonding between the patient and the health staff. When one considers that DM requires continuous and complex care, demonstration of interest on the part of professionals can establish and 
maintain bonds with the objective to promote health and the protection of individual patient rights ${ }^{(18)}$.

The use of descriptive phrases, such as concise messages expressed at an audible level, without the use of technical jargon and that are not dull, was apparent in most of the studied consultations. Given the need to constantly provide information and guidance to patients so they appropriately deal with their disease, the use of descriptive phrases effectively contributes to understanding such information (2).

However, the use of prescriptive and authoritative instructions such as "you have to improve your breakfast, you have to use skim milk, you have to walk and take medication at the right time" were observed in most observations. Such guidance may harm patient adherence to the therapeutic plan. Even though diet, medication and exercise are decisive factors in DM treatment, the way such behaviors were recommended does not encourage dialogue and the active participation of patients.

Additionally, there is a consensus in the literature that during the development of a DM therapeutic plan, each aspect of care should be agreed upon with patients. It is not sufficient to provide information or convince people to change certain behaviors, since being ready to change is a result of one's own process of reflection(12). In this context, professionals need to pay attention to the fundamentals of a full therapeutic relationship ${ }^{(14)}$ and seek their own continuous qualification.

Health workers need to be cautious when introducing life style changes for DM patients because the incorporation of such guidance should be progressive and participative. The imposition of prescriptions may induce feelings of powerlessness and interfere in selfcare $^{(16)}$.

Yet, in relation to the "expression" group, the technique of "listening reflectively" was used in all consultations provided by the nurse and Nutritionist 2, corroborating the findings of a study addressing nurses in hospital service ${ }^{(14)}$. Listening reflectively is an active process that requires the concentration of attention, energy and time on the part of the professionals involved. It is essential that professionals read between the interlines, guiding themselves by questions such as: What did s/he say?, What does it mean? What is being said? (2) However, it is believed that a high demand of patients coupled with a reduced number of physicians and nurses do not favor the use of such technique.

We observed that the physician did not use this technique during his consultations. Listening reflectively is a demonstration of respect and a valorization of patients' feelings(2); it is a means to capture aspects related to treatment that could combine with therapeutic adjustments. Such a gap may compromise the quality of care in terms of the treatment of DM.

Additionally, non-verbal communication such as gaze and facial expressions manifesting impatience associated with finger tapping on the table were observed on the part of one of the professionals. Workers generally do not realize their body language is inappropriate and that their non-verbal signs are actually harmful to patients. Such manifestations, also reported in another study ${ }^{(19)}$, may compromise the quality of interaction. A balance between verbal and non-verbal communication favors the maintenance of interpersonal relationships and should be used by nurses and other workers in a more reflective manner(1).

The techniques of the "expression" group, such as "using silence therapeutically, using phrases that are open to interpretation, repeating the last words said by the patient, returning the question asked, allowing the patient to choose the subject, verbalizing doubts, and encouraging the expression of underlying feelings", were not identified in this study and were seldom observed in another study ${ }^{(14)}$. The use of these techniques can encourage more extensive and better interactions because they facilitate the description of experiences, feelings and thoughts, enabling professionals to better known patients and, consequently, maintain interpersonal relationships more efficiently(2).

In agreement with the literature, the "clarification" group should be used by professionals with the objective to provide patients an opportunity to organize their thoughts and express themselves so that messages are

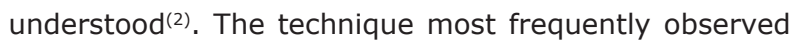
was "asking the patient to specify the agent of action", though it was only observed in two consultations provided by the nurse, in two consultations provided by the physician, and two provided by Nutritionist 1 . On these occasions, the professionals showed an ability to use this technique to clarify unclear terms used by the patients and properly guide the interaction.

Research aimed to describe therapeutic communication between nurses and patients within the hospital environment showed that the techniques from the "clarification" group, that is, asking the patient to clarify uncommon terms and describe events in a logical sequence were used only by one of the studied professionals(6). The use of such techniques was also seldom observed in a study addressing the 
delivery of care to patients undergoing bone marrow transplantation ${ }^{(14)}$.

We verified that the technique "describe events in logical sequence", not observed in this study, could have facilitated the communicative process. This result was contrary to what was reported in the study addressing communication between nurses and patients undergoing bone marrow transplantation ${ }^{(14)}$.

The "validation" group enables professionals to validate the message of patients, checking whether guidance and information provided by nurses and other professionals were understood(2). This study, besides others in the literature(7,14,20-22), shows that techniques from among this group were seldom used by the professionals. In most of the interactions, the physician, nurse and Nutritionist 1 did not check whether the patient and family members understood the diagnosis and therapeutic guidance, indicating the need to optimize the communicative process.

Verifying the extent patients understand DM treatment is essential to motivate self-care and control of the disease. The need to validate or provide feedback concerning instructions provided to patients with the disease is emphasized by researchers in the field because it is a way to identify the need to reorganize educational actions and plan care that is coherent with the patients' real and potential needs ${ }^{(12,16)}$. Encouraging actions that reduce the use of non-verbal therapeutic categories can contribute to changing the communication pattern of the studied group.

Data from this study indicate that gaps observed in the communication process between health workers and patients were also identified in the hospital and primary health care contexts, showing that human communication is complex and multidimensional and requires competencies, skills and appropriate attitudes to be put implemented(13). The data provides evidence as to how complex it is to establish full communication between workers and patients while being motivated and qualified are essential for professionals to acquire communication skills.

Even though the competence of the studied workers concerning the technical aspects of care provided for diabetes mellitus is evident, the use of communication strategies is still a challenge to clinical practice. Integral care provided to patients with DM requires great affinity among those involved; thus, those responsible for such care should become familiar with aspects related to therapeutic communication.

\section{Conclusions}

Data obtained in this study enable us to conclude that the health workers used different types of communication techniques during consultations provided to individuals with diabetes mellitus, especially those from the "expression" group. However, according to what is observed, there are difficulties for professionals to establish full therapeutic communication, since important techniques from the "clarification" and "validation" groups were not employed.

This study has limitations that impede the generalization of results. The study's design does not allow the establishment of a cause and effect relationship, the sample size is small since it represents only the personnel with higher education from a single secondary care service. There is also the fact that professionals were informed about having their consultations filmed, thus, the therapeutic actions observed in this study may not have been the same as routine ones. Further studies comparing data are suggested to deepen debate in this field and improve knowledge on the subject.

\section{References}

1. Silva MJP. O papel da comunicação na humanização da atenção à saúde. Bioética. 2002;10(2):73-88.

2. Stefanelli MC. Estratégias de comunicação terapêutica. In: Stefanelli MC, Carvalho EC. A comunicação nos diferentes contextos da enfermagem. Barueri (SP): Manole; 2005. p. 73-104.

3. Noreña-Peña AL, Cibanal-Juan L. El contexto de la interacción comunicativa: factores que influyen en la comunicación entre los profesionales de enfermería y los niños hospitalizados. Cultura de los Cuidados. 2008;23(1):70-9.

4. Pontes AC, Leitão IMTA, Ramos IC. Comunicação terapêutica em enfermagem: instrumento essencial do cuidado. Rev Bras Enferm. 2008;61(3):312-8.

5. Morais GSN, Costa SFG, Fontes WD, Carneiro AD. Comunicação como instrumento básico no cuidar humanizado em enfermagem ao paciente hospitalizado. Acta Paul Enferm. 2009;22(3):54-6.

6. Negreiros PL, Fernandes NO, Macedo-Costa KNF, Silva GRF. Comunicação terapêutica entre enfermeiros e pacientes de uma unidade hospitalar. Rev Eletr Enferm. [periódico na Internet]. 2010; [acesso 13 jan 2011]; 12(1):120-32. Disponível em: http://www.fen.ufg.br/ revista/v12/n1/pdf/v12n1a15.pdf 
7. Caprara A, Rodrigues J. A relação assimétrica médicopaciente: repensando o vínculo terapêutico. Ciênc Saúde Coletiva. 2004;9(1):139-46.

8. Dimatteo MR. Social Supp ort and patient adherence to medical treatment: A meta-análysis. Health Psychol 2004;23(2):201-18

9.Spagnuolo RS, Pereira MLT. Healthcare practices in nursing and communication: a review of the literature. Ciênc Saúde Coletiva 2007 Dez;12(6):1603-10.

10. Cardoso LS, Cezar-Vaz MR, Silva MRS da, Costa VZ da. Finalidade do processo comunicacional das atividades em grupo na Estratégia Saúde da Família. Rev LatinoAm. Enfermagem. mar-abr 2011;19(2):396-402.

11. Machado EP, Haddad JGV, Zoboli ELCP. A comunicação como tecnologia leve para humanizar a relação enfermeiro-usuário na atenção básica. Rev Bioethikos. 2010;4(4):447-52.

12. American Diabetes Association (ADA).National Standards for Diabetes Self-Management Education. Diabetes Care. 2012;35(suppl 1):s101-7.

13. Braga EM, Silva MJP. Comunicação competente. Visão de enfermeiros especialistas em comunicação. Acta Paulista Enferm. 2007;20(4):410-4.

14. Fermino TZ, Carvalho EC. A comunicação terapêutica em transplante de medula óssea: perfil do comportamento verbal e efeito de estratégia educativa. Cogitare Enferm. 2007;12(3):287-95.

15. Oliveira OS, Nóbrega MMLM, Silva ATMC, Ferreira OM Filha. Comunicação terapêutica em enfermagem revelada nos depoimentos de pacientes internados em centro de terapia intensiva. Rev Eletr Enferm. [periódico na Internet]. 2005; [acesso $14 \mathrm{dez} 2010$ ]; 7(1)5463. Disponível em: http://www.fen.ufg.br/revista/ revista7_1/original_05.htm

16. Diabetes Education Study Group. Teaching letter: diabetes education. Düsseldorf (GE): European Association for the Study of Diabetes; 2001.

17. Araújo JMF. A promoção da saúde a partir do enfoque da comunicação face a face e da percepção interpessoal entre o médico e o paciente. Derecho a Comunicar. 2010;2:154-69.

18. Haddad JGV, Zoboli ELCP. O Sistema Único de Saúde e o giro ético necessário na formação do enfermeiro. Mundo Saúde. 2010;34(1):86-91.

19. Araújo MMT, Silva MJP, Puggina ACG. A comunicação não-verbal enquanto fator iatrogênico. Rev Esc Enferm USP. $2007 ; 41(3): 419-25$.
20. López ML, Carvalho EC. La comunicación terapêutica durante instalación de venoclisis; uso de la similación filmada. Rev. Latino-Am. Enfermagem. 2006;14(5):658-65.

21. Victor ACS, Matsuda LM, Saalfed SMS, Évora YDM. Physician team verbal communication: perceptions and needs of visitors at an adult intensive care unit. Acta Scientiarum, Health Sci. 2003;25(2):199-206.

22. Sparapani VC, Borges ALV, Dantas IRO, Pan R, Nascimento LC. A criança com Diabetes Mellitus Tipo 1 e seus amigos: A influencia dessa interação no manejo da doença. Rev. Latino-Am. Enfermagem. jan-fev 2012;20(1):117-25. 